\title{
Southern hemisphere biodiversity and global change: data gaps and strategies
}

Lynda E. Chambers ${ }^{1}$, Phoebe Barnard ${ }^{2,3}$, Elvira S. Poloczanska ${ }^{4,5}$, Alistair J. Hobday ${ }^{6 *}$, Marie R. Keatley ${ }^{7}$, Nicky Allsopp ${ }^{8}$, Les G. Underhill ${ }^{9}$

${ }^{1}$ Australian Bureau of Meteorology, GPO Box 1289, Melbourne, Vic. 3001, Australia

${ }^{2}$ Climate Change BioAdaptation and Biodiversity Futures Programs, South African National Biodiversity Institute, P/Bag X7, Claremont 7735, South Africa

${ }^{3}$ DST-NRF Centre of Excellence at the Percy FitzPatrick Institute of African Ornithology, University of Cape Town, Rondebosch 7701, South Africa

${ }^{4}$ CSIRO Oceans and Atmosphere, Brisbane, Qld 4067, Australia

${ }^{5}$ Global Change Institute, University of Queensland, St Lucia, Qld 4067, Australia

${ }^{6}$ CSIRO Oceans and Atmosphere, Castray Esplanade, Hobart, Tas 7001, Australia

${ }^{7}$ School of Ecosystem and Forest Sciences, The University of Melbourne, Water Street, Creswick, Victoria, 3363, Australia

${ }^{8}$ South African Environmental Observation Network, SAEON Fynbos Node, P/Bag X7, Claremont 7735, South Africa

${ }^{9}$ Animal Demography Unit, Department of Biological Sciences, University of Cape Town, Rondebosch, South Africa

*Corresponding author: Alistair.Hobday@csiro.au, ph: 61362325310

Running head: Southern hemisphere data gaps and strategies

This is the author manuscript accepted for publication and has undergone full peer review but has not been through the copyediting, typesetting, pagination and proofreading process, which may lead to differences between this version and the Version of Record. Please cite this article as doi: 10.1111/aec.12391

This article is protected by copyright. All rights reserved. 


\begin{abstract}
Long-term datasets needed to detect the impacts of global change on southern biodiversity are still scarce and often incomplete, challenging adaptation planning and conservation management. Biological data are probably most limited in arid countries and from the oceans, where natural environmental variability ('noise') means that long time-series are required to detect the 'signal' of directional change. Significant national and international investment and collaboration are needed for most southern nations to reliably track biodiversity trends and improve conservation adaptation to rapid climate change. Emerging early warning systems for biodiversity, incorporating regional environmental change drivers, citizen science and regional partnerships, can all help to compensate for existing information gaps and contribute to adaptation planning.
\end{abstract}

Keywords: early warning systems, data recovery, climate change, adaptation, citizen science

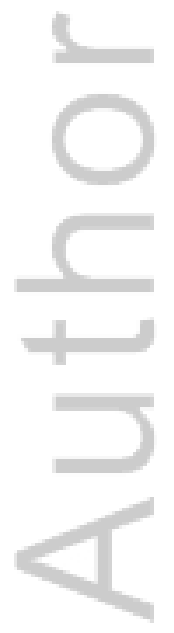

This article is protected by copyright. All rights reserved. 


\section{Introduction}

Warming of the climate system is "unequivocal," with almost the entire globe experiencing surface warming over the last hundred years (IPCC 2014). However, impacts on atmospheric and oceanic processes, climatic trends and ecosystem processes tend to be regional in terms of their manifestation and implications (Hewitson et al. 2014; IPCC 2014). The substantial regional variation in observations of climate change impacts arises as the impacts themselves vary across the globe and due to regional differences in research effort and investment (Hewitson et al. 2014). For example, there are few observations of impacts on natural systems from the equatorial regions or the southern hemisphere ocean and land masses compared to the temperate regions of the northern hemisphere (Rosenzweig et al. 2007, 2008; Chambers et al. 2014; Hansen \& Cramer 2015; Pearce-Higgins et al. 2015). Consequently, a lack of impacts attributed to climate change within a region does not necessarily imply that such impacts have not occurred but is the result of factors such as a lack of data of sufficient resolution and length or scientific studies to provide process understanding (Hansen \& Cramer 2015).

The sensitivity and vulnerability of natural systems to climatic change is determined by a number of factors that may all be changing simultaneously. Regional variation in natural climate variability such as the El Niño-Southern Oscillation (ENSO) or Pacific Decadal Oscillation (PDO) and in other anthropogenic drivers of change such as land-use change, mean that understanding of climate and other drivers of responses and subsequent adaptation planning are not necessarily applicable across all regions (e.g. Boulton et al. 2008; Ruane et al. 2015). For example, attribution of species responses to climate change is overwhelmingly 
based on work in northern temperate regions, particularly the North American and European land masses where current species distributions are heavily influenced by the retreat and configuration of ice sheets after the Last Glacial Maximum (LGM) (e.g. Huntley 2005). These factors of bias and data availability and quality can have important policy and conservation implications, given that some of the least-well observed regions (e.g. central Africa and small island nations in the Pacific) are vulnerable to climate change (Allison et al. 2009; Bell et al. 2011). Not surprisingly, these are also some of the regions where research and implementation of adaptation practices is also lagging. In addition, much of the southern hemisphere is distinctly lacking in terms of observational networks and research investment. In such a context, there is an urgent need to locate, collate, digitize, evaluate, analyse and continue or restart long-term southern datasets, and where necessary, initiate new ones (e.g. Andersen et al. 2014; Gerstner et al. 2015, Lynch et al. 2014). This will provide a platform for evidence-based decision making.

Here, we do not exhaustively review the capacity of southern hemisphere nations to build and use datasets to assess and reduce regional risks from climate change. Rather we emphasize the urgent need to invest in southern biodiversity and climate informatics. We consider the risks to southern ecosystems and species and the need for southern insights and data to inform regional planning. We emphasize dangers for sustainable national development given the data vacuum in which policy and planning often take place in developing southern countries (UNEP 2012). We highlight simple components of emerging ‘early warning systems' (Barnard \& De Villiers 2012) for southern biodiversity based on existing long-term and citizen science datasets. Importantly, citizen science can help 
supplement specific gaps in professional capacity in developing southern countries (Dickenson et al. 2010). Geographical areas of high capacity within the south can also help catalyse significant regional improvements in biodiversity management and adaptation planning, via south-north and south-south collaboration.

\section{Different hemispheres - different climates}

The tectonic breakup of Gondwana and Laurasia, the southerly and northerly supercontinents, from Pangaea beginning some 200-180 million years ago has resulted in southern taxa experiencing different palaeoclimatic histories than northern taxa. Gondwana land masses experienced lower temperature fluctuations than the northern hemisphere (EPICA Community members 2006). Climate in much of the south appears to have been more stable than in the north over the last several million years, and is likely to have contributed to the greater average age of southern species and greater endemism in tropical and southern regions (Sandel et al. 2011). As an example, contemporary temperate reptiles and amphibians are on average 1.7 million years older in the south than in the north and are considered less resilient to threats from human activities, including climatic change (Dubey \& Shine 2011). During the Last Glacial Maximum, much of northern Europe and northern America was covered by ice sheets with permafrost extending over southern Europe whereas deserts expanded over Africa and Australia (Adams \& Faure 1997). Following the retreat of the glaciers, mammals, for example, colonized western Europe from southeastern and eastern Europe, bringing together genotypes and leading to the formation of new assemblages swamping local endemism (Montgomery et al. 2014).

This article is protected by copyright. All rights reserved. 
Contemporary hemispheric climatic differences are due in part to the relative lack of land mass south of the equator (a 4:1 ocean surface area to land ratio in the south vs 1.5:1 in the north). Furthermore, the area of land south of $30^{\circ} \mathrm{S}$ declines sharply, in contrast to the northern hemisphere where the bulk of the land mass lies between $40-65^{\circ} \mathrm{N}$. As a result of this more oceanic setting, only the most southerly or high-altitude land regions in the southern hemisphere have extreme seasonal cold or permanent snow, and lands are more generally warm to hot and arid (Graetz \& Wilson 1996; Hurrell et al. 1998).The large heat capacity of the oceans also drives generally smaller-amplitude seasonal cycles in temperature (Hurrell et al. 1998; Whetton et al. 1996) and smaller temperature variations in southern countries (Markgraf \& McGlone 2005). In the south, biological responses on land and in coastal waters are thus often more strongly driven by aseasonal and unreliable rainfall (Dean et al. 2009; Meynecke et al. 2006; Wantièz et al. 1996) and fire (Bond et al. 2004; Markgraf \& McGlone 2005; Bowman et al. 2014) than by day length or temperature (Midgley et al. 2007; Nicholls 1996).

Arid regions of Africa, Australia and South America have variable rainfall and runoff from year to year, with coefficients of variation of 60-100\% or more (McMahon et al. 2007), and are strongly influenced by large-scale drivers of climatic variability on interannual to decadal scales, such as the El Niño-Southern Oscillation (ENSO), Indian Ocean Dipole (IOD) or Southern Annular Mode (SAM or Antarctic Oscillation, AAO) (Nicholls 1996; Ropelewski \& Halpert 1987; Harris et al. 2008, Philippon et al. 2011). El Niño events are associated with droughts in eastern Australia, southern Africa, Papua New Guinea and Indonesia, and with heavy rainfall in Ecuador and Peru (Whetton et al. 1996). Fire regimes 
are also influenced by ENSO and are important drivers of floristic life histories and ecosystem distributions in much of the south (Bond et al. 2004; Harris et al. 2008; Van der Werf et al. 2008).Changes in fire frequency as a result of climate change also have large impacts in southern ecosystems (Bowman et al. 2014).

\section{Different biogeographies}

Hemispheric climatic differences have also resulted in an asymmetry between latitude and species richness, with larger species diversity in the south than in the north, possibly as a result of larger temperatures at equivalent southern latitudes (e.g. Dunn et al. 2009), although extreme reductions in rainfall in certain regions might have triggered considerable biodiversity loss (Dynesius \& Jansson 2000). In some terrestrial systems, increasing aridification and the seasonality of rainfall in some areas can drive diversification (Cowling et al. 1996). Aridification has influenced the dominance of non-equilibrium processes in arid southern ecosystem dynamics (Dean et al. 2009). Given historical and projected declines in rainfall and increases in fire frequency (Lough \& Hobday 2011; Bowman et al. 2014; Hope et al. 2015), the floral biodiversity hotspots in southwest Australia (Yates et al. 2010) and South Africa (Pressey et al. 2003; Raimondo et al. 2009; http://redlist.sanbi.org/index.php; Yates et al. 2010) may be at considerable risk. These and other megadiverse areas of the south present important and urgent challenges for understanding species responses to climate. For some land animals, non-climate conservation threats are also higher in the southern hemisphere, particularly in Oceania (Kingsford et al. 2009), and knowledge of biodiversity is poor (Schipper et al. 2008). These fundamental, often poorly understood, differences between

This article is protected by copyright. All rights reserved. 
hemispheres, observed and debated at length since Charles Darwin (Darwin 1859), suggest that insights from northern systems should be cautiously applied to the south.

\section{Southern hemisphere data gaps}

Climatic observations can be regionally sparse across most of the tropics and south, which can also limit aspects of the validation and downscaling of general circulation models (GCMs) (Stott \& Thorne 2010; Hewitson et al. 2013). GCMs may less reliably simulate atmospheric dynamics in these regions (Stott et al. 2010), and hence make projections on which to base decisions more uncertain. In addition, the importance of multi-decadal climatic variability, coupled with regional variability driven by land use change or other factors, requires time-series of many decades to detect a climatic change signal (Stott et al. 2010; Hobday \& Evans 2013).

Long-term biological datasets relevant to assessing impacts of climate change are overwhelmingly located in the north, especially North America and Europe (Root et al. 2003; Midgley et al. 2007; Pacifici et al. 2015), but exceptions exist in transitioning economies (e.g. Loos et al. 2015). The northern bias in long-term datasets reflects the histories of learned northern institutions and organisations, but also differences in distribution of land masses and human populations between the two hemispheres. Indeed, some $90 \%$ of the world's population lives in the northern hemisphere, with half of these living at latitudes above $27^{\circ} \mathrm{N}$.

The dearth of animal biodiversity datasets in the south is, however, by no means uniform. Brazil, Uruguay, Chile, Australia, New Zealand, South Africa and Namibia 
represent southern countries which have made major strides in compiling and making accessible long-term animal and ecological datasets (e.g. http://www.ilternet.edu/membernetworks, http://www.ala.org.au/), but many other countries have patchy and unconsolidated data. In many countries the process of documentation is itself relatively recent, biodiversity institutions and projects are under-funded, and publication in international peer-reviewed journals is rare (Barnard 1995; Gevers 2009). The most common long-term biological datasets in the south are based on bird atlases (distribution) and nest record schemes (phenology and demography) (Box 1). Securing these datasets institutionally, and involving civil society in data collection, is essential (De Villiers 2009; Barnard \& De Villiers 2012; Andersen et al. 2014).

Few countries anywhere in the world have comprehensive long-term biodiversity data to support the development of detailed climatic change adaptation programs, but the lack of data and capacity to interpret it in policy, planning and management contexts is acute in much of the south. Basic national vegetation maps and terrestrial or marine biodiversity atlases either do not exist in some African and South American countries, or are unrevised since colonial times. Even relatively well-resourced countries such as Australia, New Zealand, Brazil, Chile and South Africa are poor in long time-series data compared to countries in Europe, Asia and North America (Figure 1). Coastal marine mammal and fish datasets are common, due both to economic and conservation values (e.g. Gilchrist 1896; Atkinson et al. 2011); however, spatial coverage of observations is still patchy and data lacking compared to northern areas (Schipper et al. 2008; Kaschner et al. 2011; Chambers et al. 2013; Pacifici et al. 2015).

This article is protected by copyright. All rights reserved. 
On land, southern long-term datasets are often only available for vegetation type, floristic distribution, bird distribution and relative abundance, and occasionally large mammal distribution (Figure 1). These are thus used by necessity as proxies for other taxa in biodiversity area prioritization (e.g. Reyers et al. 2007) and climatic vulnerability analysis (Barnard \& Thuiller 2008). In the absence of more comprehensive data, these are used to highlight potential problem areas for species in other groups (Bibby 1999), but results must be interpreted cautiously, as patterns in one species may not reflect biodiversity or threat patterns in another (e.g. Orme et al. 2005).

Species atlases seldom collect information on a species predators, mutualists, or food resources. This supplemental information is often crucial in predicting complex impacts of climatic change, such as altered competitive dominance or disrupted pollinator-plant relationships between species (e.g. birds (Ahola et al. 2007, Geerts 2011) and intertidal fauna (Poloczanska et al. 2008)). A lack of knowledge about rates of change, trophic interactions, and response thresholds hampers adaptation planning (Balmford \& Bond 2005). The data and monitoring required could seem prohibitive, even in well-resourced countries. An alternative which may require identification of adequate ecological indicator species and involvement of local communities in monitoring change should benefit conservation responses. Efforts to enhance capacity through citizen science projects are increasing (Silvertown 2009) (Box 2), although not widely or rapidly enough to compensate for the projected rate of change across many species.

This article is protected by copyright. All rights reserved. 


\section{Socioeconomic impediments to adaptation}

Climatic change, especially if compounded by land use change and biotic invasions, has disproportionate effects on many of the countries least equipped to handle it. Climatic impacts are expected to be significant to severe in many southern hemisphere arid and small island countries, and those already struggling to cope with basic development imperatives of poverty, literacy, health, employment or social unrest. The Intergovernmental Panel on Climate Change (IPCC) detailed the anticipated vulnerabilities of Africa, small Pacific island nations, and other developing regions of the southern hemisphere (IPCC 2014). Many people in these countries rely directly on biological resources for their livelihoods (e.g. Bell et al. 2009), and are particularly vulnerable to climatic change impacts. Due to its combination of aridity, low financial resources and sometimes weak institutional capacity, Africa is considered the continent of highest vulnerability to climatic change, from both land and ocean impacts (Diffenbaugh et al. 2007; Allison et al. 2009; Niang et al. 2014). Initiatives for climatic change research on biodiversity impacts in the world's poorest nations could thus be overwhelmed by social and economic stress if human adaptation is not clearly linked to ecosystem health (Hobday \& Midgley 2013).

A major challenge for countries with developing or transitional economies is accessing capability to downscale and analyse climatic and biological data, and applying the results to adaptation planning. For example, statistical ecology and GCM downscaling, applied to environmental change analysis and synthesis, are prioritized as 'scarce skill' gaps in South Africa's emerging national strategies for biodiversity and global change human capital development. Partnerships between Australia and Pacific island countries have also 
delivered downscaled climate information to overcome capacity gaps (Australian Bureau of Meteorology \& CSIRO 2011) and provided a platform for adaptation planning.

\section{Early warning systems for rapid environmental change}

Developing nations dominate the south, and many national environmental agencies are poorly resourced and regarded as politically peripheral. In the context of imperfect data, limited capacity, and potentially misleading ecological paradigms, how can countries of the south improve their adaptation planning for biodiversity and development? Advances could be made through adopting an 'early warning system' approach to monitoring biodiversity change (Box 1). Such an approach links best available datasets, analytical and advanced modeling skills, citizen science, technological innovation, and the explicit incorporation of meaningful environmental change drivers, such as fire or rainfall seasonality to the needs of policy, planning and management (Barnard \& de Villiers 2012; Andersen et al. 2014).

The collection, collation, analysis and interpretation of baseline environmental information needs focussed investment and training (Andersen et al. 2014). This area is often, and perhaps understandably, seen by governments in developing countries, as a lower priority than investment in health, education and employment creation. However, it can be a modest and cost-effective investment in proactive and adaptive national planning, especially where human well-being can be strongly linked to ecosystem health, such as through ecosystembased adaptation to climate change (Hobday \& Midgley 2013). In many cases, such as Namibia and South Africa, this is just a matter of strategic reorientation and integration of existing long-term datasets (e.g. van Jaarsveld et al. 2007; de Villiers 2009; Barnard \& de 
Villiers 2012), the harnessing of civil society enthusiasm and capacity (Harrison et al. 1997, 2008), and the establishment of a platform for targeted, scientifically robust planning and policy support products (e.g. Barnard \& de Villiers 2012). The onus is thus on the scientific and environmental planning communities to demonstrate the utility and cost-effectiveness of existing biodiversity data as components of early warning systems.

The model systems used in many countries to support decision-making related to famine, drought, desertification, severe weather events and other environmental risks can be readily adapted to support biodiversity and environmental health decision making. These model systems perform better if long-term data are available for validation. A few countries have invested in remarkable national inventories of substantial long-term datasets, such as South Africa (e.g. Macdonald \& Crawford 1988). More commonly, valuable component data are not available from electronic databases, and are often fragmented, institutionally insecure, undervalued, and/or guarded as private intellectual property. Where appropriate, these at-risk datasets need to be identified, institutionally secured and continued or expanded. Many countries have undervalued historical long-term biological data and archived them; once these records are extracted from archives, they can be used to advise managers and policy makers of potential global change impacts and conservation adaptation options (Gioia 2009). The value of the effort to recover data is usually a function of the age, completeness, documentation and uniqueness of the dataset, but need not be expensive. For example, recovering and digitizing data collected by the Guinean Trawl Survey in the early 1960s off West Africa is estimated to have cost less than $0.5 \%$ of the original survey cost (Zeller et al. 2005). Historical information on the timing of species life-cycles in the Australian 
environment is sourced by reviewing journal and other written records (such as farm experiment cards), and digitizing the phenological observations they contain, through modestly funded projects such as Australian PhenoArc (Keatley \& Chambers 2010). Valuable data have also been recovered from state archives, newspapers and diaries by the Antarctic Islands Legacy Project of the University of Cape Town (http://academic.sun.ac.za/cib/antarcticlegacy/index.htm).

While many datasets are not yet long or spatially broad enough to draw reliable conclusions or parameterize predictive models, even relatively short-term datasets can represent important historical or current baselines. These data can often be enhanced at low cost through citizen science initiatives and integrated into a more coherent national or regional system (Boxes 1 and 2). Southern countries with greater resources, for example Australia, New Zealand and South Africa, might only need reorientation of their own national priorities to invest sufficiently in this coordination, but many others cannot do this without international investment and cooperation in informatics. Where national frameworks for such investment do not yet exist, channeling funds through multilateral conventions or international environmental observation bodies can potentially avoid inefficient or patchy bilateral support.

\section{Strengthening the capacity of the south}

One cost-effective way to strengthen the capacity of the south to adapt to climatic change is to invest modestly in the fundamental informatics capacity to demonstrate the type and magnitude of climatic change impacts. This would also allow greater contributions to global fora such as the Convention on Biological Diversity, IPCC, United Nations Framework 
Convention on Climate Change and the Intergovernmental Platform on Biodiversity and Ecosystem Services. Further investment by the global community in informatics capacity in the south, particularly less-resourced countries, is a crucial yet prudent step towards informing adaptation and environmental management. It will also lead to more inclusive participation of southern nations at international fora, less dependence on future aid, and better documentation of climate impacts on natural resources, economies and societies. Investment in regional bioinformatics and conservation data centres and multinational environmental observation systems may be preferred when institutional capacities of small nations are limited.

Given the urgency of the biodiversity and climate crises, it is probably impractical to try to achieve basic national biodiversity data capacity in all countries. For smaller or less well-resourced nations, regional centres already deliver benefits for data collation and analysis needs. Several South American countries, for example, have conservation data centres linked to North American institutions (e.g. http://www.natureserve.org). These centres develop and support in-country capacity to manage biodiversity information, and provide technical and scientific support for the regional activities of international conservation organizations.

Readily assessable multinational observation systems are required for effective biodiversity conservation and management. The Group on Earth Observations Biodiversity Observation Network (GEOBON) aims to create a global network from local, national and international activities, including retrieving data in museums and herbaria, although, there is still a shortage of biodiversity data for certain systems. A comprehensive biodiversity 
observation network can only be achieved through considerable investment in data collection in data-poor countries and regions, as emphasized by international organizations. While the Convention on Biological Diversity's Global Taxonomy Initiative (www.cbd.int/gti) recognises that numerous specimens are still undescribed in herbaria and museums, limiting the comprehensiveness of species distribution data, Conabio (www.conabio.gob.mx), BiotaFapesp (www.biota.org.br/), Sabonet (www.bgci.org/africa/sabonet) and the African Plants Initiative (http://apps.kew.org/herbcat/gotoApi.do) all show what strides can be made in developing or digitizing biological specimen databases in relatively short periods. Important foci of some of these have been the repatriation of data and development of web metadatabase portals to host long-term data sets and aid data interpretation.

\section{Planning for the future - data are still important}

Given that ecosystem and species responses to climatic change can be non-linear, long timeseries are critical to detect thresholds and tipping points (Hsieh et al. 2005; Chambers et al. 2015; Litzow et al. 2016) and represent the frontline in detecting and responding to change. Many governments, institutions, and funding agencies have wavered in their support for longterm data collection. In Europe, for example, many long-term time-series were discontinued in the 1980s, when long-term monitoring was perceived as 'poor science' without hypothetico-deductive aims, and research shifted towards process-oriented studies (Duarte $e t$ al. 1992; Southward et al. 2005; Silvertown 2009). But even discontinued and noncontinuous data are useful, and online platforms increasingly support such data archiving. Such historical data can be retrieved and revisited for climate change insights. Collecting and integrating diverse biological datasets of varying length over large regions will allow the

This article is protected by copyright. All rights reserved. 
analysis and improved predictive modeling of data at spatial and temporal scales relevant to climatic change (Huntley et al. 2010; Vandepitte et al. 2010), and encourage the exploration of ways in which southern species are responding to change.

Species responses to climate change are complex and multi-faceted. Distributional, demographic, behavioural and phenological studies on species and ecosystems are thus essential to help identify and prioritize conservation actions and land use planning. Citizen science must play an increasing role in data collection (Box 2). Lessons from the north (Balmford \& Bond 2005; Loos et al. 2015), as well as ClimateWatch in Australia (Box 2) and SABAP2 (Second Southern African Bird Atlas Project, e.g. de Villiers 2009), suggest that citizen science programs readily and very cost-effectively gather valuable basic data for tracking and understanding environmental change. Such programs offer promise, both as components of early warning systems of environmental change, and to increase understanding of the responses of southern ecosystems and species to rapid change in the face of low institutional capacity. Investment in southern data collection, collation, collaboration, analysis and interpretation is therefore crucial to reduce the impacts of climatic change in the under-studied southern hemisphere and improve the effectiveness of adaptive management.

\section{Acknowledgements}

We thank our respective institutions and the thousands of civil society volunteers and fellow scientists who have contributed to long-term environmental change datasets of the south. PB

This article is protected by copyright. All rights reserved. 
acknowledges support from the South African National Research Foundation. Comments from the editor and two reviewers improved the context of several points made in the paper.

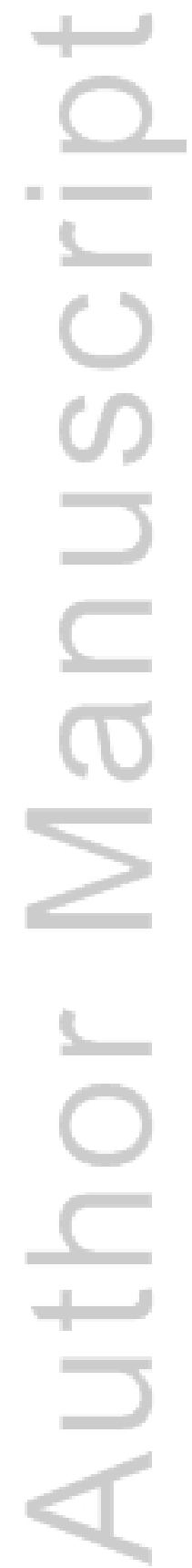

This article is protected by copyright. All rights reserved. 


\section{References}

Adams J.M. \& Faure H. (1997) Preliminary vegetation maps of the world since the Last Glacial Maximum: an aid to archaeological understanding. Journal of Archaeological Science 24, 623-647.

Ahola M.P., Laaksonen T., Eava T. \& Lehikoinen E. (2007) Climate change can alter competitive relationships between resident and migratory birds. J. Anim. Ecol. 76, 1045-1052.

Allison E.H., Perry A.L., Badjeck M.-C. et al. (2009) Vulnerability of national economies to the impacts of climate change on fisheries. Fish Fish. 10, 173-196.

Andersen, A., Beringer, J., Bull, C. M., et al (2014) Foundations for the future. A long-term plan for Australian ecosystem science. Austral Ecology 39, 739-748.

Atkinson L.J., Leslie R.W., Field J.G. \& Jarre A. (2011) Changes in demersal fish assemblages on the west coast of South Africa, 1986-2009. African J. Marine Science 33, 157-170.

Australian Bureau of Meteorology and CSIRO (2011) Climate Change in the Pacific: Scientific Assessment and New Research. Volume 1: Regional Overview. Volume 2: Country Reports.

Balmford A. \& Bond W. (2005) Trends in the state of nature and their implications for human well-being. Ecol. Lett. 8, 1218-1234.

Barnard P. (1995) Scientific research traditions and collaboration in tropical ecology. Trends Ecol. Evol. 10, 38-39.

Barnard P. \& De Villiers M. (2012) Biodiversity early warning systems: South African citizen scientists monitoring change. South African National Biodiversity Institute, Pretoria, South Africa. 14 pp. ISBN: 978-0-620-51837-6, available at http://www.sanbi.org.za/sites/default/files/documents/documents/biodiversitybooklet20 12barnard.pdf and http://zoology.uct.ac.za/pdf/Biodiversity_booklet_2012.pdf.

Barnard P. \& Thuiller W. (2008) Global change and biodiversity: future challenges. Biol. Lett. 4, 553-555.

Beaugrand G. (2004) The North Sea regime shift: causes, mechanisms and consequences. Prog. Oceanogr.60, 245-262.

Beaumont L.J., McAllan I.W. \& Hughes L. (2006) A matter of timing: changes in arrival and departure dates of Australian migratory birds. Global Change Biol. 12, 1-16.

Bell J.D., Kronen M., Vunisea A., Nash W.J. et al. (2009) Planning the use of fish for food security in the Pacific. Marine Policy 33, 64-76.

Bell, J. D., Johnson, J. E. \& Hobday, A. J. Eds. (2011) Vulnerability of Tropical Pacific Fisheries and Aquaculture to Climate Change. Noumea, New Caledonia, Secretariat of the Pacific Community.

Bibby C.J. (1999) Making the most of birds as environmental indicators. In: Adams, N.J. and Slotow, R.H. (eds) Proc. 22 Int. Ornithol. Congr., Durban, South Africa. Ostrich 70, 81-88.

Bond W.J., Woodward F.I. \& Midgley G.F. (2004) The global distribution of ecosystems in a world without fire. New Phytol.165, 525-538. 
Botts E.A, Erasmus B.F.N. \& Alexander G.J. (2015) Observed range dynamics of South African amphibians under conditions of global change. Austral Ecol. 40, 309-317.

Boulton A.J., Boyero L., Covich A.P., Dobson M., Lake S. \& Pearson R. (2008) Are tropical streams ecologically different from temperate streams? In Dudgeon D. (ed.) Tropical Stream Ecology. Elsevier, Cambridge. ISBN: 978-0-12-088449-0.

Bowman D.M. J.S., Murphy B. P., Neyland D. L. J., Williamson G. J. \& Prior L. D. (2014) Abrupt fire regime change may cause landscape-wide loss of mature obligate seeder forests. Global Change Biol. 20, 1008-1015.

Butt N., Pollock L.J. \& McAlpine C.A. (2013) Eucalypts face increasing climate stress. Ecol. Evol. 3, 5011-5022.

Chambers L.E. (2008) Trends in migration timing of south western Australian birds and their = relationship to climate. Ети 108, 1-14.

Chambers L.E. (2010) Altered avian seasonal movements in a peri-urban environment: climate related? Ети 110, 48-53.

Chambers L.E., Altwegg R., Barbraud C. et al. (2013) Phenological changes in the Southern Hemisphere. PLOS ONE 8, e75514.

Chambers L.E., Beaumont L. \& Hudson I. (2014) Continental scale analysis of bird migration timing: influences of climate and life history traits - a generalised mixture model clustering approach. Int. J. Biometeorol. 58, 1147-1162.

Chambers L.E., Gibbs H., Weston M.A. \& G.C. Ehmke (2008) Spatial and temporal variation in Masked Lapwing breeding. Ети 108, 115-124.

Chambers L.E., Patterson T., Hobday A.J. et al. (2015) Determining trends and environmental drivers from long-term marine mammal and seabird data: examples from Southern Australia. Reg. Environ. Change 15, 197-209.

Cowling R.M., Rundel P.W., Lamont B.B., Arroyo M.K. \& Arianoutsou M. (1996) Plant diversity in Mediterranean-climate regions. Trends Ecol. Evol. 11, 362-366.

Darwin C. (1859) The Origin of Species and the Descent of Man in Relation to Sex. J. Murray, London.

de Villiers M.S. (ed) (2009) Birds and environmental change: Building an early warning system in South Africa. South African National Biodiversity Institute, Pretoria, 14pp. ISBN 978-0-620-45305-9, available at www.sanbi.org and http://www.adu.org.za/docs/climate_change_booklet.pdf.

Dean W.R.J., Barnard P. \& Anderson M.D. (2009) When to stay, when to go: trade-offs for southern African arid-zone birds in times of drought. S. Afr. J. Sci. 105, 25-28.

Dickinson, J. L., B. Zuckerberg \& D. N. Bonter (2010) Citizen Science as an Ecological Research Tool: Challenges and Benefits. Ann. Rev. Ecol. Syst. 41: 149-172.

Diffenbaugh N.S., Giorgi F., Raymond L \& Bi X. (2007) Indicators of $21^{\text {st }}$ century socioclimatic exposure. Proc. Natl Acad. Sci. 104, 20195-20198.

Duarte C.M., Cebrian J. \& Marba N. (1992) Uncertainty of detecting sea change. Nature 356, 190.

Dubey S. \& Shine R. (2011) Geographic variation in the age of temperate-zone reptile and amphibian species: southern hemisphere species are older. Biol. Lett.7, 96-97.

Dunn A.M. \& Weston M.A. (2008) A review of terrestrial bird atlases of the world and their application. Ети 108, 42-67.

This article is protected by copyright. All rights reserved. 
Dunn R.R., Agosti D., Andersen A.N., Arnan X. et al. (2009) Climatic drivers of hemispheric asymmetry in global patterns of ant species richness. Ecol. Lett. 12, 324-333.

Dynesius M. \& Jansson R. (2000) Evolutionary consequences of changes in species' geographical distributions driven by Milankovitch climate oscillations. Proc. Natl. Acad. Sci. USA 97, 9115-9120.

EPICA Community members (2006) One-to-one coupling of glacial climate variability in Greenland and Antarctica. Nature 444, 195-198.

Evans K,L, Tyler C., Blackburn T.M. \& Duncan R.P. (2003) Changes in the breeding biology of the Welcome Swallow (Hirundo tahitica) in New Zealand since colonisation. Emu 103, 215-220.

Geerts S. (2011) Assembly and disassembly of bird pollination communities at the Cape of - Africa. PhD Thesis, Stellenbosch University.

Gerstner E.-M., Bachmann Y., Hahn K., Lykke A.M. \& Schmidt M. (2015) The West African Data and Metadata Repository - a long-term data archive for ecological datasets from West Africa. Flora et Vegetatio Sudano-Sambesica 18, 3-10.

Gevers W. (2009) Globalizing science publication. Science 325, 920.

Gilchrist J.D.F. (1896) Report of the Marine Biologist, Department of Agriculture, Cape of Good Hope, for January-March 1896. Cape Town; Government Printer: pp. 12.

Gioia P. (2009) Managing biodiversity data within the context of climate change: towards best practice. Austral Ecol. 35, 392-405.

Graetz R.D. \& Wilson M.A. (1996) North-South: where is the divide? In Gaimbelluca T.W. and Henderson-Sellers A. (eds) Climate Change: Developing Southern Hemisphere Perspectives, Wiley, pp. 3-33.

Hansen G. \& Cramer W. (2015) Global distribution of observed climate change impacts. Nat. Clim. Chang.5, 182-185.

Harris S., Tapper N., Packham D., Orlove B. \& Nicholls N. (2008) The relationship between the monsoonal summer rain and dry-season fire activity of northern Australia. Int. J. Wildland Fire 17, 674-684.

Harrison J.A., Allan D.G., Underhill L.G., Herremans M., Tree A.J., Parker V. \& Brown C.J. (eds) (1997) The Atlas of Southern African Birds, vol. 1. Non-passerines, vol. 2. Passerines. BirdLife South Africa, Johannesburg.

Harrison J.A., Underhill L.G. \& Barnard P. (2008) Seminal legacy of the Southern African Bird Atlas Project. S. Afr. J. Sci. 104, 82-84.

Hays G.C., Richardson A.J. \& Richardson C. (2005) Climate change and plankton. Trends Ecol. Evol. 20, 337-344.

Hewitson B., Janetos A.C., Carter T.R., Giorgi F., Jones R.G., Kwon W.-T., Mearns L.O., Schipper E.L.F., \& van Aalst M. (2014) Regional context. In: Climate Change 2014: Impacts, Adaptation, and Vulnerability. Part B: Regional Aspects. Contribution of Working Group II to the Fifth Assessment Report of the Intergovernmental Panel on Climate Change [Barros, V.R., C.B. Field, D.J. Dokken, M.D. Mastrandrea, K.J. Mach, T.E. Bilir, M. Chatterjee, K.L. Ebi, Y.O. Estrada, R.C. Genova, B. Girma, E.S. Kissel, A.N. Levy, S. MacCracken, P.R. Mastrandrea, and L.L.White (eds.)]. Cambridge University Press, Cambridge, United Kingdom and New York, NY, USA, pp. 11331197. 
Hewitson B., Lennard C., Jack C., Coop L. (2013) Statistical and dynamical downscaling in CORDEX-Africa: differing views on the regional climate. EGU General Assembly 2013, 7-12 April, 2013, Vienna, Austria, id. EGU2013-11702.

Hobday A. J. \& Evans K. (2013) Detecting climate impacts with oceanic fish and fisheries data. Clim. Change 119, 49-62.

Hobday, A. J. \& Midgley G. F. (2013). Ecosystem Impacts and Adaptation. In Climate Adaptation Futures. Eds J. Palutikof, S. L. Boulter, A. J. Ash et al. Oxford, Blackwell: 257-266.

Hope P., Grose M. R., Timbal B., Dowdy A. J., Bhend J., Katzfey J. J., Bedin T., Wilson L. \& Whetton P. H. (2015) Seasonal and regional signature of the projected southern Australian rainfall reduction. Aust Meteorol Ocean 65, 54-71.

Hsieh C.-H., Glaser S.M., Lucas A.J. \& Sugihara G. (2005) Distinguishing random environmental fluctuations from ecological catastrophes for the North Pacific Ocean. Nature 435, 336-340.

Huntley B. (2005) North temperate responses. In: Lovejoy T.E. and Hannah L. (eds) Climate Change and Biodiversity, Yale University Press, pp. 109-124.

Huntley B., Barnard P., Altwegg R., Chambers L. et al. (2010) Beyond bioclimatic envelopes: Dynamic species' range and abundance modeling in the context of climatic change. Ecography 33, 1-6.

Hurrell J.W., van Loon H. \& Shea D.J. (1998) The mean state of the troposphere. In: Karoly DJ, Vincent DG (eds) Meteorology of the Southern Hemisphere, pp.1-46, American Meteorological Society, Boston. Meteor. Monogr. 27(49).

IPCC (2014) Summary for Policymakers. In: Climate Change 2014: Impacts, Adaptation, and Vulnerability. Part A: Global and Sectoral Aspects. Contribution of Working Group II to the Fifth Assessment Report of the Intergovernmental Panel on Climate Change [Field, C.B., V.R. Barros, D.J. Dokken, K.J. Mach, M.D. Mastrandrea, T.E. Bilir, M. Chatterjee, K.L. Ebi, Y.O. Estrada, R.C. Genova, B. Girma, E.S. Kissel, A.N. Levy, S. MacCracken, P.R. Mastrandrea, and L.L. White (eds.)]. Cambridge University Press, Cambridge, United Kingdom and New York, NY, USA, pp. 1-32.

Kaschner K., Tittensor D. P., Ready J., Gerrodette T. \& Worm B. (2011) Current and Future Patterns of Global Marine Mammal Biodiversity. PLoS ONE 6, 1932-6203.

Keatley M.R. \& Chambers L.E. (2010) Australia. In Hudson I.L. and Keatley M.R. (eds) Phenological Research: Methods for Environmental and Climate Change Analysis, Springer, Dordrecht, pp. 31-33.

Keatley M.R., Fletcher T.D., Hudson I.L. \& Ades P.K. (2002) Phenological studies in Australia: potential application in historical and future climate analysis. Int. J. Climatol. 22, 1769-1780.

Kingsford R.T., Watson J.E.M., Lundquist C.J. et al. (2009) Major conservation policy issues for biodiversity in Oceania. Conserv. Biol. 23, 834-840.

Lindenmayer, D. B., Burns, E. L., Tennant, P., et al. (2015) Contemplating the future: acting now on long-term monitoring to answer 2050's questions. Austral Ecology 40, 213-224.

Litzow M.A., Hobday A.J., Frusher S.D., Dann P. \& Tuck G.N. (2016) Detecting regime shifts in marine systems with limited biological data: an example from southeast Australia. Prog. Oceanog. DOI: 10.1111/jiec.12382. 
Loos, J., Horcea-Milcu A. I., Kirkland P., Hartel, T. Osvath-Ferencz M. \& Fischer J. (2015) Challenges for biodiversity monitoring using citizen science in transitioning socialecological systems. J. Nature Cons. 26: 45-48.

Lough, J. M. \& Hobday, A. J. (2011) Observed climate change in Australian marine and freshwater environments. Mar. Freshw. Res. 62, 984-999.

Lynch T. P., Morello E.B., Evans K., Richardson A.J., Rochestern W., Steinberg C.R., Roughan M., Thompson P., Middleton J.F., Feng M., Sherrington R., Brando V., Tilbrook B., Ridgway K., Allen S., Doherty P., Hill K. \& Moltmann T.C. (2014) IMOS National Reference Stations: A Continental-Wide Physical, Chemical and Biological Coastal Observing System. PLoS ONE 9(12): e113652.doi:10.1371/journal.pone.0113652.

Macdonald I.A.W. \& Crawford R.J.M., eds (1988) Long-term data series relating to southern Africa's renewable natural resources. S. Afr. Nat. Sci. Prog. Rep. 157, 1-497.

Markgraf V. \& McGlone M. (2005) Southern temperate ecosystem responses. In: Lovejoy T.E. and Hannah L. (eds) Climate Change and Biodiversity, Yale University Press, pp 142-156.

McMahon T.A., Vogel R.M., Peel M.C. \& Pegram G.G.S. (2007) Global streamflows - Part 3: Country and climate zone characteristics. J. Hydrol. 347, 272-291.

Menzel A., Sparks, T.H., Estrella N. et al. (2006) European phenological response to climate change matches the warming pattern. Global Change Biol. 12, 1969-1976.

Meynecke J.-O., Lee S.Y., Duke N.C. \& Warnken J. (2006) Effect of rainfall as a component of climate change on estuarine fish production in Queensland, Australia. Est. Coast. Shelf Sci. 69, 491-504.

Midgley G.F., Chown S.L. \& Kgope B.S. (2007) Monitoring effects of anthropogenic climate change on ecosystems: a role for systematic ecological observation? S. Afr. J. Sci. 103, $1-5$.

Montgomery W.I., Provan J., McCabe A.M. et al. (2014) Origin of British and Irish mammals: disparate post-glacial colonization and species introductions. Quaternary Sci. Rev. 98, 144-165.

Niang I., Ruppel O.C., Abdrado M.S., Essel A., Lennard C., Padgham J. \& Urquhart P. (2014) Africa. In: Climate Change 2014: Impacts, Adaptation, and Vulnerability. Part B: Regional Aspects. Contribution of Working Group II to the Fifth Assessment Report of the Intergovernmental Panel on Climate Change. Barros, V.R., C.B. Field, D.J. Dokken, M.D. Mastrandrea, K.J. Mach, T.E. Bilir, M. Chatterjee, K.L. Ebi, Y.O. Estrada, R.C. Genova, B. Girma, E.S. Kissel, A.N. Levy, S. MacCracken, P.R. Mastrandrea, L.L. White (eds). Cambridge University Press, Cambridge, United Kingdom and New York, NY, USA, pp. 1199-1265.

Nicholls N. (1996) Modelling climate variability. In: Gaimbelluca T. W and HendersonSellers A (eds) Climate Change: Developing Southern Hemisphere Perspectives, Wiley, pp. 131-143.

Orme C.D.L., Davies R.G., Burgess M. et al. (2005) Global hotspots of species richness are not congruent with endemism or threat. Nature 436, 1016-1019.

Pacifici M., Foden W.B., Visconti P. et al. (2015) Assessing species vulnerability to climate change. Nat. Clim. Chang. 5, 215-225. 
Parmesan C. \& Yohe G. (2003) A globally coherent fingerprint of climate change impacts across natural systems. Nature 421, 37-42.

Pearce-Higgins J.W., Ockendon N., Baker D.J., Carr J., White E.C., Almond R.E.A., Amano T., Bertram E., Bradbury R.B., Bradley C., Butchart S.H.M., Doswald N., Foden W., Gill D.J.C., Green R.E., Sutherland W.J. \& Tanner E.V.J. (2015) Geographical variation in species' population responses to changes in temperature and precipitation. Proc. R. Soc. B 282:20151561. http://dx/doi.org/10.1098/rspb.2015.1561.

Philippon, N., Rouault, M., Richard, Y. \& Favre, A. (2011) The Influence of ENSO on winter rainfall in South Africa. Int. J. Climatol. 32, 2333-2347.

Poloczanska E.S., Brown C., Sydeman W., Kiessling W., Schoeman D., Moore P., Brander K., Bruno J.F., Buckley L.B., Burrows M.T., Duarte C.M., Halpern B.S., Holding J., - Kappel C.V., O'Connor M.I., Pandolfi J.M., Parmesan C., Schwing F., Thompson S.A., Richardson A.J. (2013) Global imprint of climate change on marine life. Nature Clim. Change 3, 919-925.

Poloczanska E.S., Hawkins S.J., Southward A.J. \& Burrows M.T. (2008) Modelling the response of populations of competing species to climate change. Ecology 89, 31383149.

Pressey R., Cowling R.M. \& Rouget M. (2003) Formulating conservation targets for biodiversity pattern and process in the Cape Floristic Region, South Africa. Biol. Conserv. 112, 99-127.

Raimondo, D., Von Staden, L., Foden, W., Victor, J.E., Helme, N.A., Turner, R.C., Kamundi, D.A., Manyami, P.A. (eds) 2009. Red list of South African plants 2009. Strelitzia 25, South African National Biodiversity Institute, Pretoria

Reyers B., Rouget M., Jonas Z. et al. (2007) Developing products for conservation decisionmaking: lessons from a spatial biodiversity assessment for South Africa. Diversity Distrib. 13, 608-619.

Richardson A. \& Poloczanska E. (2008) Ocean science: under-resourced, under threat. Science 320, 1294-1295.

Root T.L., Price J.T., Hall K. R. et al. (2003) Fingerprints of global warming on wild animals and plants. Nature 421, 57-60.

Ropelewski C.F. \& Halpert M.S. (1987) Global and regional scale precipitation patterns associated with El Niño/Southern Oscillation. Mon. Weather Rev. 115, 1606-1626.

Rosenzweig C., Casassa G., Karoly D.J. et al. (2007) Assessment of observed changes and responses in natural and managed systems. In: Parry M.L., Canziani O.F., Palutikof J.P., van der Linden P.J. and Hanson C.E. (eds) Climate Change 2007: Impacts, Adaptation and Vulnerability. Contribution of Working Group II to the Fourth Assessment Report of the Intergovernmental Panel on Climate Change, Cambridge University Press, pp. 79-131

Rosenzweig C., Karoly D., Vicarelli M. et al. (2008) Attributing physical and biological impacts to anthropogenic climate change. Nature 453, 353-358.

Ruane S., Torres-Carvajal O. \& Burbrink F.T. (2015) Independent demographic responses to climate change among temperate and tropical milksnakes (Colubridae: genus Lampropeltis). PLoS One 10(6):e0128543. doi:10.1371/journal.pone.0128543. 
Sandel B., Arge L., Dalsgaard B., Davies R. G., Gaston K. J., Sutherland W. J. \& Svenning J.-C. (2011) The influence of late Quaternary climate-change velocity on species endemism. Science 324, 660-664.

Schipper J., Chanson J.S., Chiozza F. et al. (2008) The status of the world's land and marine mammals: diversity, threat, and knowledge. Science 322, 225-230.

Scholes R.J., Mace G.M., Turner W. et al. (2008) Toward a global biodiversity observing system. Science 321, 1044-1045.

Silvertown J. (2009) A new dawn for citizen science. Trends Ecol. Evol. 24, 467-471.

Simmons R., Barnard P., Dean W.R.J., Midgley G.F., Thuiller W. \& Hughes G. (2004) Climate change and birds: perspectives and prospects from southern Africa. Ostrich 75, 295-308.

Southward A.J., Langmead O., Hardman-Mountford N.J. et al. (2005) Long-term oceanographic and ecological research in the western English Channel. Adv. Mar. Biol. 47, 1-105.

Stott P.A. \& Thorne P.W. (2010) How best to log local temperatures? Nature 465, 158-159.

Stott P.A., Gillett N.P., Hegerl G.C. et al. (2010) Detection and attribution of climate change: a regional perspective. WIREs Climate Change 1, 192-211.

UNEP (2012) Review of data needs. Chapter 8 in Global Environmental Outlook 5: Environment for the future we want. United Nations Environment Programme, http://www.unep.org/geo/pdfs/geo5/GEO5_report_C8.pdf

Van der Werf G.R., Randerson J.T., Giglio L, Gobron N. \& Dolman A.J. (2008) Climate controls on the variability of fires in the tropics and subtropics. Glob. Biogeochem. Cycles 22, GB3028.

Van Jaarsveld A.S, Pauw J.C., Mundree S., Mecenero S., Coetzee B.W.T., Alard G.F. (2007) South African Environmental Network: vision, design and status. S. Afr. J. Sci. 103, 289-194.

Vandepitte L., Vanhoorne B., Kraberg A. et al. (2010) Data integration for European marine biodiversity research: creating a database on benthos and plankton to study large-scale patterns and long-term changes. Hydrobiol. 644, 1-13.

Wantièz L., Harmelin-Vivien M. \& Kulbicki M. (1996) Spatial and temporal variation in a soft-bottom fish assemblage in St Vincent Bay, New Caledonia. Mar. Biol. 125, 801812.

Whetton P., Pittock A.B., Labraga J.C., Mullan A.B. \& Joubert A. (1996) Southern Hemisphere climate: comparing models with reality. In: Gaimbelluca T.W. and Henderson-Sellers A .(eds) Climate Change: Developing Southern Hemisphere Perspectives, Wiley, pp. 89-130.

Woods R.W. \& Woods A. (1997) Atlas of breeding birds of the Falkland Islands. Anthony Nelson, Oswestry, UK.

Yates C.J., Elith J, Latimer A.M., le Maitre D, Midgley G.F., Schurr F.M. \& West A.G. (2010) Projecting climate change impacts on species distributions in megadiverse South African Cape and Southwest Australian Floristic Regions: Opportunities and challenges. Austral Ecol. 35, 374-391.

Zeller D., Froese R. \& Pauly D. (2005) On losing and recovering fisheries and marine science data. Mar. Policy 29, 69-73. 


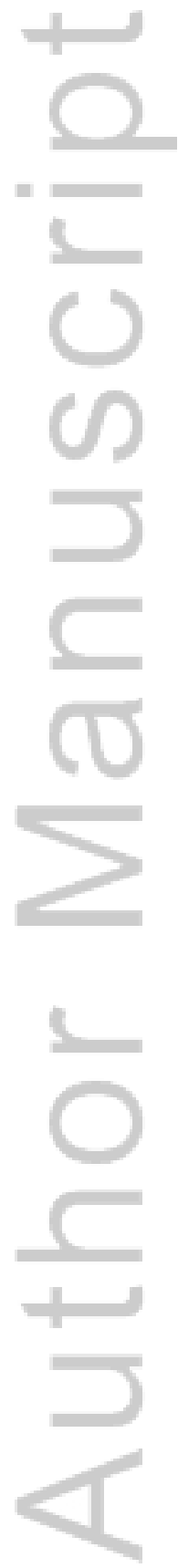

This article is protected by copyright. All rights reserved. 


\section{Box 1. Building early warning systems with imperfect capacity}

Early warning systems for biodiversity under rapid environmental change could help countries with severe capacity constraints to mobilize existing data effectively. South Africa's emerging early warning system for biodiversity and climatic change (e.g. de Villiers 2009), for example, links multiple design features to the improvement of adaptive planning:

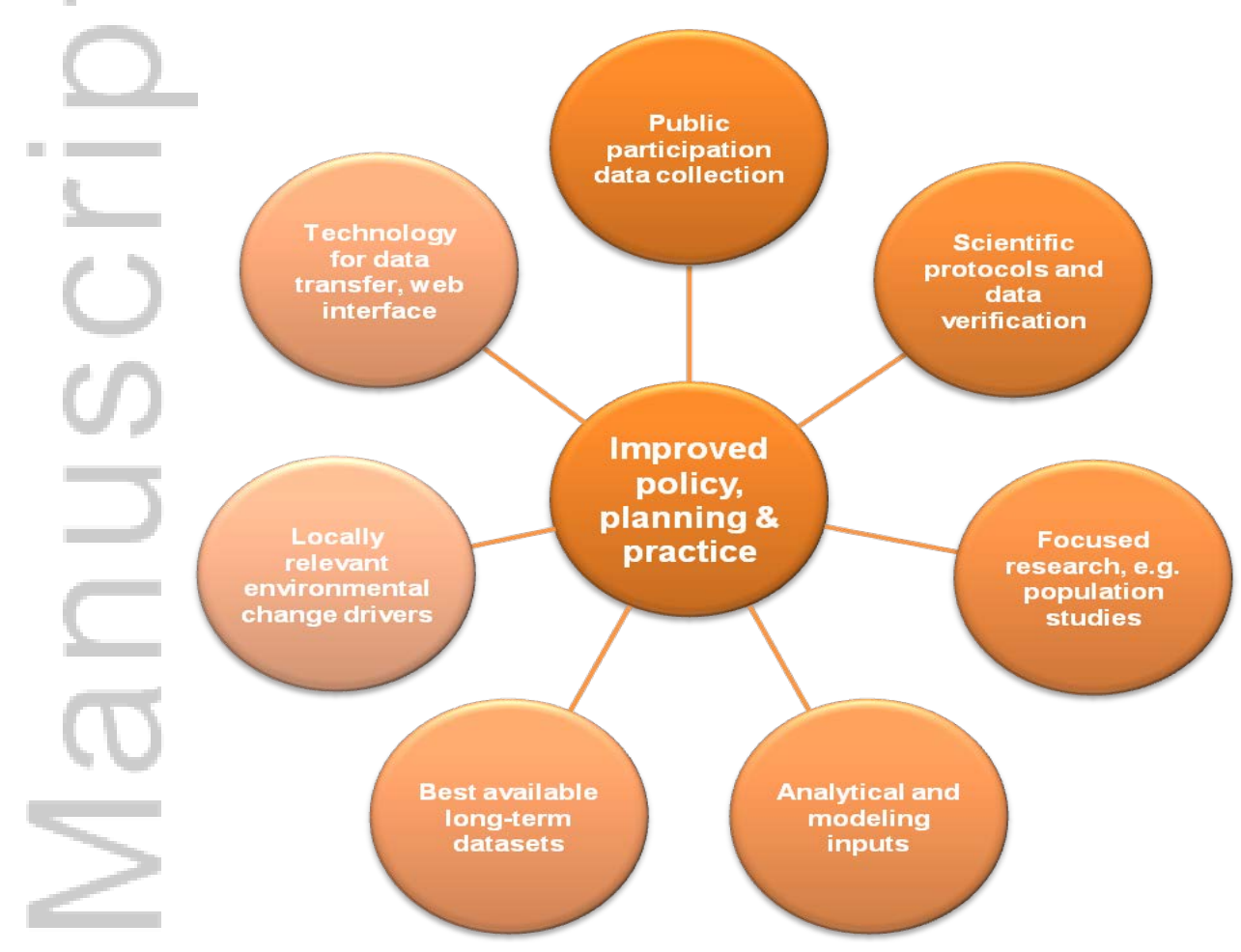

In that country, long-term bird atlas, ringing and terrestrial and wetland count datasets are being integrated into the core of a national early warning system for environmental change (de Villiers 2009, Barnard \& de Villiers 2012), with atlas-type projects recently added for reptiles, frogs, and butterflies (www.adu.org.za; Botts et al. 2015).

In Africa, as elsewhere, mobile telecommunications technologies are transforming biodiversity data collection and submission, including "smart phone" GPS loggers for animal movements (e.g. www.cybertracker.co.za/) and the integration of hand-held species distribution data loggers with Google Earth ${ }^{\mathrm{TM}}$ maps and grid layers (e.g. http://sabap2.adu.org.za/). Technological mobility has facilitated participation in 
environmental monitoring programs by younger, more upwardly mobile members of civil society in various parts of Africa, including where conventional land-based telecommunications infrastructure has not been extensive. The enhanced use of digital technologies and informatics applications is already broadening social participation in environmental issues.

Bird data are by far the most common of animal diversity datasets in the south around which to build early warning systems, with bird atlases providing fast-emerging insights into species responses to environmental change in southern Africa (Harrison et al. 1997) (http://sabap2.adu.org.za); Kenya (http://kenyamap.adu.org.za); Australia (http://www.birdlife.org.au/projects/atlas-and-birdata); New Zealand (www.bird.org.nz/atlas.htm); and the Falkland Islands (Woods \& Woods 1997). Nest record schemes are important datasets on phenology and demography in Australia (http://www.birdlife.org.au/projects/atlas-and-birdata) and southern Africa (www.adu.org.za), though few cover more than a few decades (see also Dunn \& Weston 2008). Such data have been used to analyse changes in migration and breeding timing and success as indicators of resilience to recent climatic changes (e.g. Chambers et al. 2008; Evans et al. 2003). Fine- to medium-scale atlas data can also be used to model species distribution changes with first or second generation bioclimatic envelope approaches (e.g. Huntley et al. 2010; Simmons et al. 2004). Other integrated early-warning web platforms include Sao Paulo's Biota Fapesp atlas (http://www.fapesp.br/en/4662) and the Australian Institute of Marine Science Long-term Monitoring Program www.aims.gov.au/docs/research/monitoring/reef/reef-monitoring.html). The US Long Term Ecological Research program (www.lternet.edu) added the Moorea Coral Reef (Society Islands of French Polynesia) to their network in 2004.

This article is protected by copyright. All rights reserved. 


\section{Box 2. ClimateWatch: an example of citizen science data for detecting species climatic responses}

Data collected by volunteer citizens provide valuable information on how species in the southern hemisphere respond to long-term climatic variability and change, and are one of the few sources of large-scale and long-term biological data. These 'citizen scientists' greatly enhance the geographical coverage of biological observations, often with greater temporal coverage and much lower costs than could otherwise be achieved, and their work builds biodiversity proficiency and interest in civil society. Yet measures need to be in place to ensure that the data collected are stored in an easily accessible and central location, and that funding and institutional support are available to ensure data curation, longevity and application.

Data collected by citizen volunteers can be used to analyse changes in migration timing and its relationship to migratory distance, and changes in the timing of seasonal movement and its relationship to local and distant climate (Beaumont et al. 2006; Chambers 2008, 2010;

Chambers et al. 2014). These studies highlight the influence of rainfall changes on movement in Australian species. Similarly, both rainfall and temperature have been shown to be important drivers of the timing of flowering in eucalypts (Myrtaceae) (Keatley et al. 2002; Butt et al. 2013).

Australia's ClimateWatch (http://www.climatewatch.org.au) project involves the public in biodiversity monitoring on a national scale, targeting a wide array of terrestrial and marine species. The project allows individuals to gain hands-on understanding of the science of climatic change by tracking selected plant and animal indicator species and their behaviour throughout the year. The project recognises that successful data collection on this scale is only possible through multi-sector input and an approach that engages the community in the scientific process with the data collected being freely available to all through the Atlas of Living Australia (http://www.ala.org.au). The format of data collected allows scientists to look not only at changes in the phenology of species, but also at range shifts. 

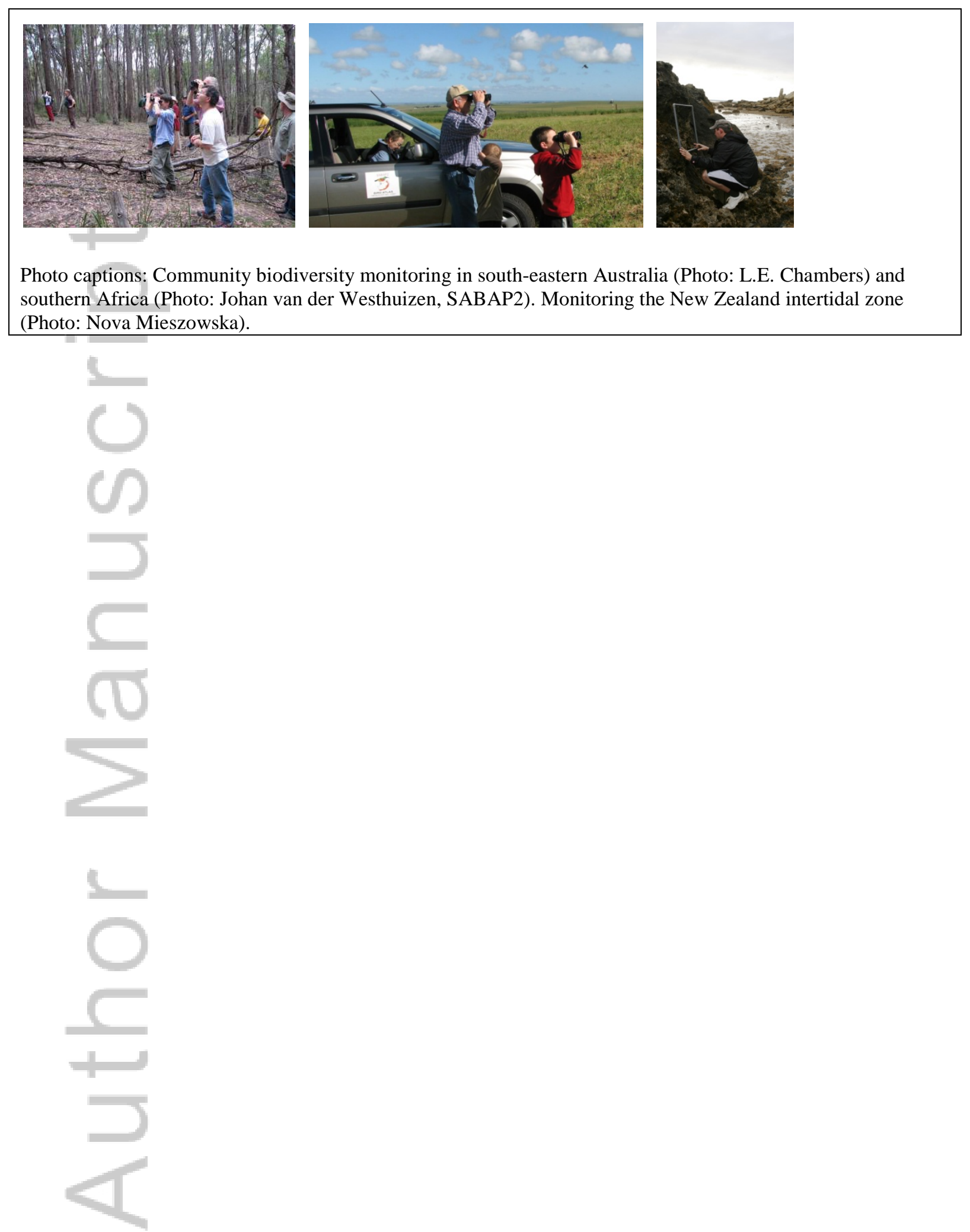

This article is protected by copyright. All rights reserved. 


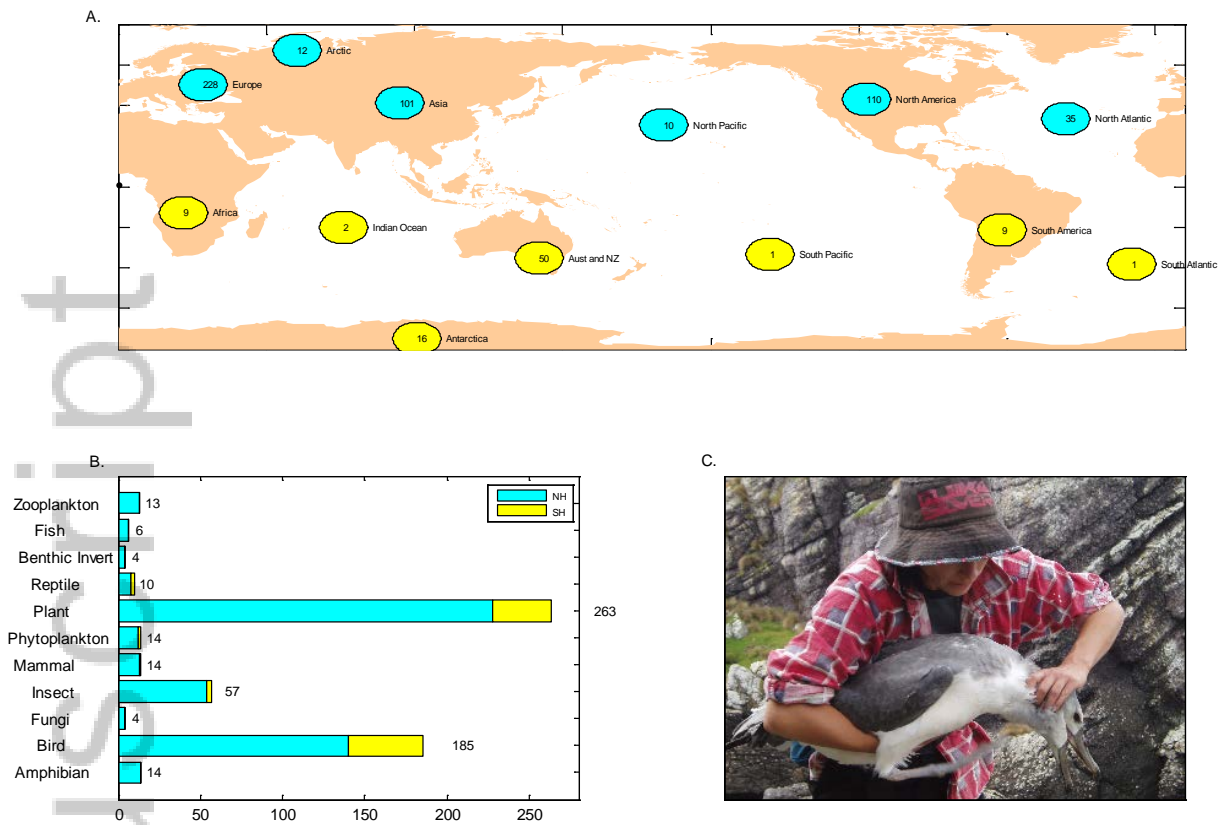

Figure 1. Distribution of studies (peer-reviewed publications) investigating observed changes in phenology in relation to recent climate change. A. Distribution of phenology studies by major regions, including ocean and land masses. Blue circles: locations in the northern hemisphere; yellow: southern hemisphere. Number in circles = number of studies $\mathbf{B}$. Frequency of phenology studies by taxon with location of studies by hemisphere shown. Taxonomic groups were extracted for each study in A. Total sample size is indicated beside each bar. C. Sampling albatross as part of a long term study in Tasmania (Photo: Alistair Hobday). A-B: All studies of phenology for which the role of climate change as a driver was investigated and include studies where responses were shown to be consistent with theoretical expectations under climate change, equivocal or no change observed. Criteria for inclusion if studies were: (i) climate change was discussed, (ii) observations spanned at least 19 years and (iii) data after 1990 were included. Further details are given in Poloczanska et al. (2013). Studies were sourced from Parmesan and Yohe (2003), Root et al. (2003), Rozenzweig et al. (2007), Chambers et al. (2013) and Poloczanska et al. (2013) and updated with recent literature identified in searches of ISI Web of Science.

This article is protected by copyright. All rights reserved. 


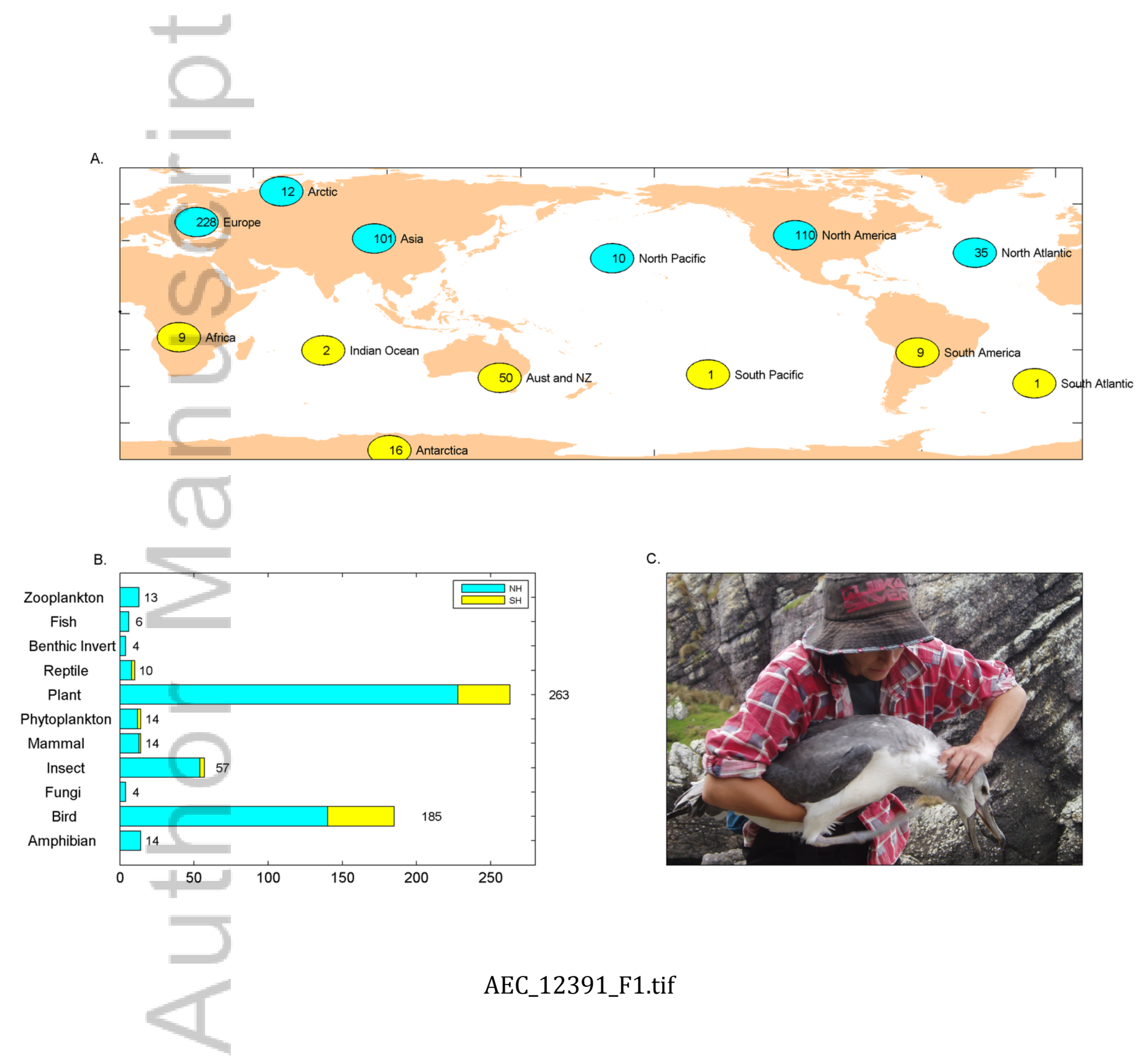

This article is protected by copyright. All rights reserved. 


\section{University Library}

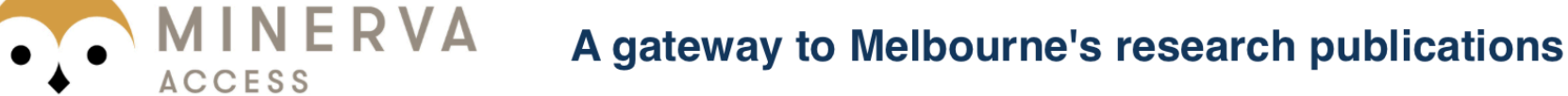

Minerva Access is the Institutional Repository of The University of Melbourne

Author/s:

Chambers, LE;Barnard, P;Poloczanska, ES;Hobday, AJ;Keatley, MR;Allsopp, N;Underhill, LG

Title:

Southern Hemisphere biodiversity and global change: Data gaps and strategies

Date:

2017-02-01

Citation:

Chambers, L. E., Barnard, P., Poloczanska, E. S., Hobday, A. J., Keatley, M. R., Allsopp, N. \& Underhill, L. G. (2017). Southern Hemisphere biodiversity and global change: Data gaps and strategies. AUSTRAL ECOLOGY, 42 (1), pp.20-30. https://doi.org/10.1111/aec.12391.

Persistent Link:

http://hdl.handle.net/11343/291641 